\title{
NOVEL ROLE OF ANTIPLATELET AGENTS (ASPIRIN PLUS CLOPIDOGREL) IN AN INCOAGULABLE BLOOD OF A VICTIM OF RUSSELL'S VIPER SNAKEBITE
}

\author{
BAWASKAR H. S. (1)
}

(1) Bawaskar Hospital and Research Center, Mahad District, Raigad, Maharashtra, India.

ABSTRACT: Snake antivenom is a specific antidote to the venom action, neutralizing the circulating venom. However, it fails to neutralize the venom fixed to target organs such as platelets, renal tubules, etc. Russell's viper venom initiates rapid coagulation in a victim by activating blood platelets, factors $\mathrm{V}, \mathrm{X}$, and anticoagulant cofactors. Activation of thrombin, resulting in formation of micro-thrombi, fibrinolysis, and a vicious cascade, sets in. Inhibition of activated platelets by aspirin (cyclooxygenase inhibitor) and clopidogrel (ADP receptor inhibitor) helps to break this vicious circle induced by Russell's venom and may initiate the natural physiological clotting mechanism. They can be utilized as an adjuvant treatment.

KEY WORDS: Russell's viper, coagulation, fibrinolysis, aspirin, clopidogrel.

\section{CORRESPONDENCE TO:}

H. S. BAWASKAR, Bawaskar Hospital and Research Center, Mahad District, Raigad, Maharashtra, 402301, India. Email: himmatbawaskar@rediffmail.com. 
H. S. Bawaskar NOVEL ROLE OF ANTIPLATELET AGENTS (ASPIRIN PLUS CLOPIDOGREL) IN AN INCOAGULABLE BLOOD OF A VICTIM OF RUSSELL'S VIPER SNAKEBITE. J. Venom. Anim. Toxins incl. Trop. Dis., 2006, 12, 1, p.138

\section{CASE REPORT}

A thirty-five years old man was bitten by a Russell's viper (Figure 1) on the dorsum of his left foot, at 2 p.m., while harvesting grass for the cattle. A 2.5-feet long snake was killed by a bystander and was identified as a Russell's viper at the city of Mahad, Maharashtra, India. The victim experienced severe pain at the bite site. There was a continuous oozing of blood from the two fangs marks. He developed marked edema on the foot together with ecchymosis and blebs (Figure 2). He felt giddy, sweated profusely all over the body, had massive hematemesis and abdominal pain. He bled from an abrasion on his chest. At 3:30 p.m., he reported to the government hospital, where a medical officer administered $100 \mathrm{ml}$ of Haffkine polyvalent anti-snake venom and noted a blood pressure of $70 \mathrm{mmHg}$, and was hence reported to the Mahad hospital at 6:30 p.m. His blood remained incoagulable (during 20 minutes of the whole blood test). Platelets count was 36,000 per $\mathrm{ml}$. Blood $(10 \mathrm{ml})$ was collected for in vitro study. He was given two bottles of fresh blood and intravenous crystalloid solution. His blood pressure was maintained at $100 \mathrm{mmHg}$ by using dopamine, 2.5 microgram/per/kg, and $80 \mathrm{mg}$ furosemide intravenously. Polyvalent anti-snake venom $(50 \mathrm{ml})$ added to $5 \%$ dextrose $(500 \mathrm{ml})$ was administered over six hours. At the end of this six-hours period, blood coagulated within 10 minutes. He passed $600 \mathrm{ml}$ urine in 8 hours of admission. The man was immunized for tetanus, given Penicillin and metronidazole for wound infection. He was discharged on the $5^{\text {th }}$ day after admission. The detailed hematological investigations at the rural setting are not available.

\section{EXPERIMENT}

The blood collected $(2 \mathrm{ml})$ was distributed into four dry glass test tubes (Figure 3):

Tube 1 - blood + aspirin + clopidogrel = clotted

Tube 2 - blood + clopidogrel $=$ not clotted

Tube $3-$ blood + aspirin $=$ not clotted

Tube 4 (Control) - blood of the victim bitten by a russell's viper

All four tubes kept undisturbed. They were observed every 10 minutes. At the end of 30 minutes the blood in the test tube 1 coagulated while in the other tubes it remained incoagulable. This is the first report of its kind. Since it is a preliminary report, no controlled or repeated experiments were done. 
H. S. Bawaskar NOVEL ROLE OF ANTIPLATELET AGENTS (ASPIRIN PLUS CLOPIDOGREL) IN AN INCOAGULABLE BLOOD OF A VICTIM OF RUSSELL'S VIPER SNAKEBITE. J. Venom. Anim. Toxins incl. Trop. Dis., 2006, 12, 1, p.139

Acute bleeding from the bite site or abrasions; bleeding from internal organs such as adrenal, pituitary gland; disseminated intravascular coagulopathy; and renal failure are clinical features of envenomation by a Russell's snake.

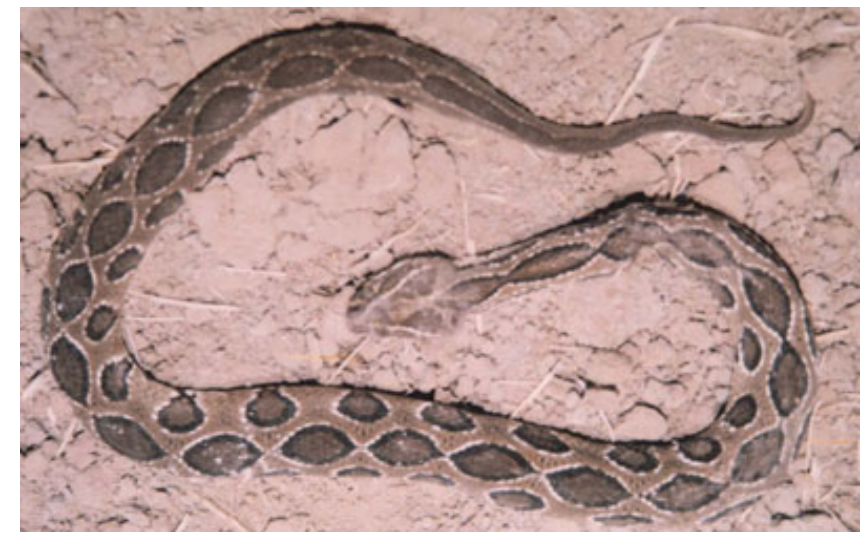

Figure 1: Russell's viper (Viper russelli). A common lethal snake in Maharashtra.

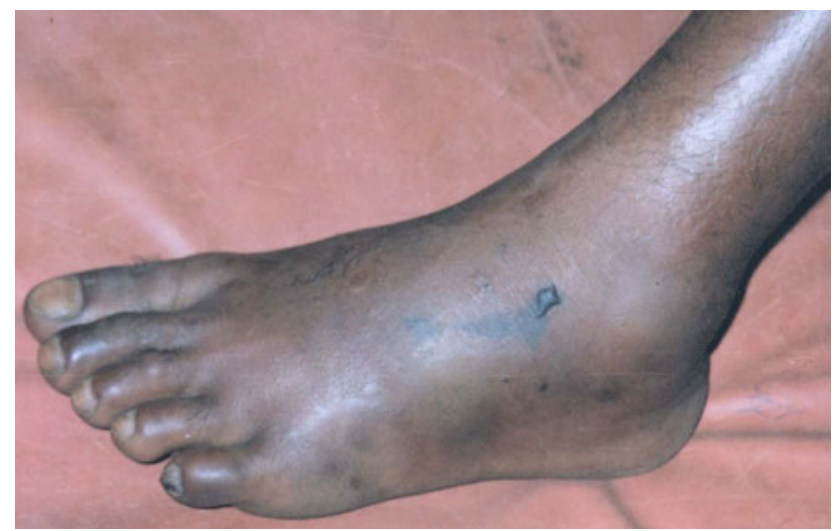

Figure 2: Swelling, blisters and echymosis at the bite site.

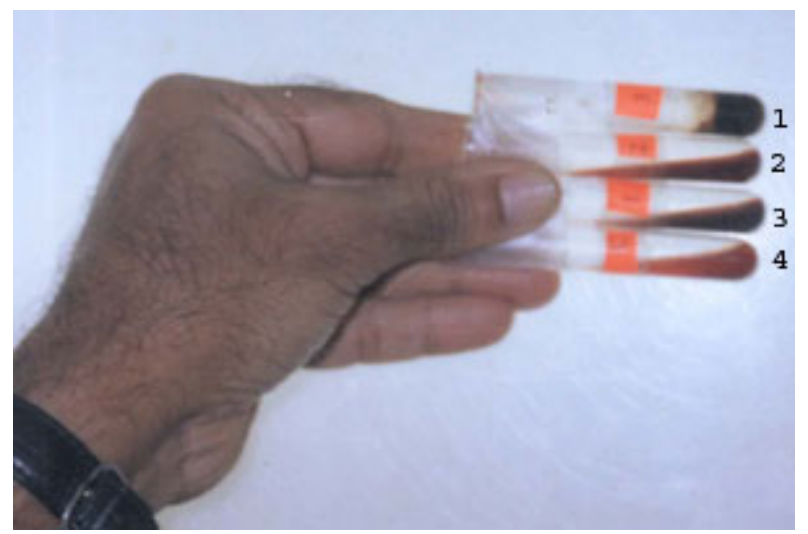

Figure 3: Test tubes used in the blood examination.

Test tube 1 - blood of victim + aspirin + clopidogrel = clot formation

Test tube 2 - blood of victim + clopidogrel = no clot formation

Test tube 3 - blood of victim + aspirin= no clot formation

Test tube 4 (control) - blood of a victim bitten by Russell's viper = no clot formation 
H. S. Bawaskar NOVEL ROLE OF ANTIPLATELET AGENTS (ASPIRIN PLUS CLOPIDOGREL) IN AN INCOAGULABLE BLOOD OF A VICTIM OF RUSSELL'S VIPER SNAKEBITE. J. Venom. Anim. Toxins incl. Trop. Dis., 2006, 12, 1, p.140

\section{DISCUSSION}

Russell's viper venom (RV) is rich in procoagulants, which activate factors $\mathrm{V}$ and $\mathrm{X}$, and thrombin, whose feedback amplifies the system by activating not only factor $\mathrm{V}$, but also factors VIII and XI. Factor VIII circulates bound to von Willebrand factor, which is an adhesive protein important for the generation of the initial platelet plug. Thrombin has the capacity to express both procoagulant and anticoagulant functions, depending on the context under which it is generated. Activation of factor XI by thrombin is another amplification loop. Thus, RV is a strong coagulant and at times the manifestation of bleeding due to consumption coagulopathy, fall in the fibrinogen level and reduction in the platelet count delays the ADP aggregation of platelet and increases the fibrinolytic activity. (5). Platelets exposed to RV showed to retain their ability to aggregate when thrombin is added to them (2). In the present case, antivenom neutralized the venom, and the administration of two bottles of blood containing inactivated fresh platelets helped to reverse the bleeding disorder. However allogenic blood transfusion is not free from complications such as bacterial infection, multiple organ failure and stroke (7).

A thrombin inhibitor, heparin is used to reverse the process in Russell's bite, provided there is no active bleeding (6). In an experiment with animals, in which antivenom was given in combination with antithrombin III, abnormal clotting induced by RV was prevented (1).

Macfarlane's historical finding was that hemophilic blood coagulated as soon as the viper venom is added, due to the activation of factor $\mathrm{V}$ by RV. (4).

Hemophilic manifestations were reported in a case treated with clopidogrel (3).

Aspirin (cyclo-oxygenase inhibitor) and clopidogrel (ADP receptor inhibitor) inhibited the activated platelets reversing the thrombin formation, and fibrinolysis was inhibited resulting in natural physiological clot (see tube 1, Figure 3). Hence, these simple and easily available antiplatelet agents can be administered as an adjuvant treatment in cases of Russell's viper envenomation, however further detailed investigations are needed as well as tests with experimental animals.

At first, though it appeared to be unsound and paradox how platelet inhibitors help to initiate a clotting in bleeding diathesis, it is easy to understand the underlying pathophysiology of the Russell's venom action on the blood clotting mechanism. 
H. S. Bawaskar NOVEL ROLE OF ANTIPLATELET AGENTS (ASPIRIN PLUS CLOPIDOGREL) IN AN INCOAGULABLE BLOOD OF A VICTIM OF RUSSELL'S VIPER SNAKEBITE. J. Venom. Anim. Toxins incl. Trop. Dis., 2006, 12, 1, p.141

\section{REFERENCES}

1 CLEMENS R., PUKRITTAYAKAMEE S., VANIJANONTA S., NONTPRASERT A., BOCK HL., CHAROENLARP P., WHITE NJ. Therapeutic effects of antivenom supplemented by antithrombin III in rats experimentally envenomed with Russell's viper (Daboia russelli siamensis) venom. Toxicon, 1995, 33, 77-82.

2 DAVEY MG., LUSCHER EF. Actions of some coagulant snake venoms on blood platelets. Nature, 1965, 207, 730-2.

3 HAJ M., DASANI H., KUNDU S., MOHITE U., COLLINS PW. Acquired haemophilia A may be associated with clopidogrel. Br. Med. J., 2004, 329, 323.

4 MAcFARLANE RG. Russell's viper venom, 1934-64. Br. J. Haematol., 1967, 13, 437-51.

5 MYINT-LWIN, WARREL DA., PHILLIPS RE., TIN-NU-SWE, TUN-PE, MAUNGMAUNG-LAY. Bites by Russell's viper (Vipera russelli siamenses) in Burma: haemostatic, vascular, and renal disturbances and response to treatment. Lancet, 1985, 2, 1259-64.

6 PAUL V., PRAHLAD KA., EARALI J., FRANCIS S., LEWIS F. Trial of heparin in viper bite. J. Assoc. Physicians India, 2003, 51, 163-6.

7 VAMVAKAS EC. Platelet transfusion and adverse outcomes. Lancet, 2004, 364, 1736-8. 